\title{
PENERAPAN EVALUASI PEMBELAJARAN ANAK USIA DINI DI TAMAN KANAK-KANAK
}

\author{
Agus Jatmiko $^{1}$, Eti Hadiati ${ }^{2}$, Mia Oktavia ${ }^{3}$, \\ ${ }^{1,2,3}$ Universitas Islam Negeri Raden Intan Lampung, Bandar Lampung, Indonesia \\ Email: agusjatmiko@ radenintan.ac.id
}

\begin{abstract}
This study aims to find out more about how the application of evaluation of early childhood learning in dharma kindergarten women bandung bandung union. The formulation of the problem in this study is "How is the Implementation of Evaluation of Early Childhood Learning in Kindergarten Dharma Wanita Bandar Lampung". This type of research is descriptive qualitative. Research data were collected through observation, interviews, and document analysis. Data were analyzed using data reduction, data display and conclusion drawing. The results showed that in the Implementation of Early Childhood Learning Evaluation in the Dharma Wanita Persatuan Bandar Lampung Kindergarten stated that of the five indicators there were four indicators that had been met including (1) Formulating or establishing activities (2) Preparing assessment tools or techniques (3) Establish assessment criteria (4) Determine grades. However, there is one indicator that has not been fulfilled, namely collecting data. Educators are lacking to collect data on the results of learning activities. Educators should routinely collect data on the results of learning activities on students who have done. This is done so that in the implementation of the recapitulation of the assessment, educators will not have difficulty describing the learning outcomes of students.
\end{abstract}

Keywords: Evaluation of AUD Learning, Educators, Kindergartens

\begin{abstract}
Abstrak
Evaluasi merupakan bagian dari komponen pembelajaran untuk mengetahui pencapaian dalam setiap pembelajaran. Tujuan penelitian ini untuk mengetahui lebih lanjut mengenai bagaimana penerapan evaluasi pembelajaran anak usia dini di taman kanak-kanak dharma wanita persatuan bandar lampung. Jenis penelitian ini adalah deskriptif kualitatif. Data penelitian dikumpulkan melalui observasi, wawancara, dan dokumen analisis. Data dianalisis menggunakan reduksi data, display data dan penarikan kesimpulan. Hasil penelitian menunjukkan bahwa dalam Implementasi Evaluasi Pembelajaran Anak Usia Dini di Taman Kanak-kanak Dharma Wanita Persatuan Bandar Lampung menyatakan bahwa dari lima indikator ada empat indikator yang sudah terpenuhi diantaranya (1) Merumuskan atau menetapkan kegiatan (2) Menyiapkan alat atau teknik penilaian (3) Menetapkan kriteria penilaian (4) Menentukan nilai. Namun, ada satu indikator yang belum terpenuhi yaitu mengumpulkan data. Pendidik kurang untuk mengumpulkan data hasil kegiatan pembelajaran. Seharusnya secara rutin pendidik mengumpulkan data hasil kegiatan pembelajaran pada peserta didik yang telah dilakukan. Hal tersebut dilakukan supaya dalam pelaksanaan rekapitulasi penilaian nantinya pendidik tidak kesulitan untuk mendeskripsikan hasil pembelajaran pada peserta didik.
\end{abstract}

Kata kunci: Evaluasi Pembelajaran AUD, Pendidik, Taman Kanak-kanak 


\section{PENDAHULUAN}

Pendidikan merupakan suatu proses pemberian rangsangan agar potensi yang ada pada anak dapat berkembang secara optimal (Roza et al., 2020). Pendidikan anak usia dini adalah suatu rencana layanan bimbingan yang diberikan oleh lembaga pendidikan baik secara formal dan nonformal yang secara eksklusif diberikan untuk anak usia dini supaya pertumbuhan dan perkembangan intelektualnya menjadi ideal. Lembaga pendidikan dalam penyelenggaraan pendidikan anak usia dini antara lain kelompok bermain yang dapat kita kenal dengan play group, taman kanak-kanak, dan raudhatul athfal (Wiyani, 2015).

Bagi anak usia dini menutut ilmu dilakukan melalui kegiatan yang menyenangkan, seperti berlarian, bermain dengan benda nyata, melakukan percobaan-percobaan kecil bahkan bercocok tanam karena pendidikan anak usia dini berorientasi pada kegiatan bermain, sebagaimana kita ketahui bahwa anak belajar dan mendapatkan banyak pengalaman melalui bermain. Oleh karena itu sistem kegiatan pembelajran di Pendidikan Islam Anak Usia Dini (PIAUD) dirancang secara khusus melalui metode bermaian sambil belajar (K. Dewi, 2017).

Masa ini adalah masa emas atau yang biasa disebut dengan masa golden age dimana pada masa ini kemampuan otak anak dalam berpikir berkembang pesat hingga mencapai $80 \%$ (Uce, 2015). Hal ini menjadidasar utama mengapa pentingnya pendidikan untuk anak usia dini sebagaimana pada tahap-tahap perkembangan anak, terdapat enam aspek perkembangan yang dapat di stimulasi dalam pendidikan anak usia dini yaitu aspek perkembangan nilai moral dan agama, aspek perkembangan fisik motorik, aspek perkembangan bahasa, aspek perkembangan sosial emosional, aspek perkembangan kognitif dan aspek perkembangan seni (K. Dewi, 2017). Peran guru dan orang tua sangat penting dalam merangsang dan memfasilitasi seluruh aspek perkembangan tersebut (Munawaroh, 2017). Anak mendapatkan kesempatan dalam proses pembelajaran yang ilmiah pada pembelajaran anak usia dini. Maka dari itu adanya dampak pada kemampuan berpikir anak dan wawasan anak saat anak menempuh pendidikan selanjutnya (Lina et al., 2019).

Begitu pentingnya Pendidikan Anak Usia Dini dalam pengelolaan pendidikan masyarakat, hingga di dunia Internasional melihat bahwa salah satu aspek penentuan tingkat pembangunan suatu bangsa diukur dari tingkat pendidikan penduduknya. Berdasarkan Education Index yang dikeluarkan oleh Human Development Reports, pada 2017, Indonesia ada di posisi ketujuh di ASEAN dengan skor 0,622. Skor tertinggi diraih Singapura, yaitu 
sebesar 0,832. Peringkat kedua ditempati oleh Malaysia $(0,719)$ dan disusul oleh Brunei Darussalam (0,704). Pada posisi keempat ada Thailand dan Filipina, keduanya sama-sama memiliki skor 0,661. Hasil beberapa survei yang dilakukan oleh PBB dan lembaga swadaya masyarakat inilah, maka mau tidak mau kita harus memacu untuk meningkatkan kualitas sumber daya manusia sedini mungkin, terutama bahwa harus disadari tentang pentingnya Pendidikan Anak Usia Dini bagi setiap keluarga (Zubaidi, 2020).

Tujuan diselenggarakan pendidikan anak usia dini adalah untuk membina, menumbuhkan, dan mengembangkan seluruh potensi yang dimiliki anak pada usia dini secara optimal sehingga terbentuk perilaku dan kemampuan dasar sesuai dengan tahap perkembangannya agar memiliki kesiapan untuk memasuki pendidikan selanjutnya (Anggraini \& Kuswanto, 2019). Anak yang mendapatkan layanan yang baik semenjak usia dini memiliki harapan besar untuk meraih keberhasilan di masa mendatang. Sebaliknya, anak yang tidak mendapatkan layanan pendidikan yang memadai semenjak usia dini membutuhkan perjuangan yang cukup berat untuk pengembangan kehidupan selanjutnya (Sari \& Setiawan, 2020).

Pada dasarnya pembelajaran di PAUD bertujuan untuk mengenalkan pembelajaran aktif melalui kegiatan langsung-hand-on dalam kelompok kecil, individu, ataupun kelompok besar. Guru sejatinya tidak mengambil alih gagasan anak, dimana anak harus mengikuti gagasan guru, tetapi dorongan agar anak menjadi pembelajar aktif yang memiliki gagasan dan cara belajar sendiri. Dukungan seperti ini sangat penting untuk mendorong terbangunnya hubungan pengalaman atau pengetahuan yang sudah dimiliki anak dengan apa yang sedang pelajarinya (I. Dewi \& Suryana, 2020).

Pendidik merupakan suatu prioritas pertama dalam mewujudkan keberhasilanya suatu pendidikan, oleh karena itu melihat kemajuan zaman yang serba cepat dan canggih perlunya seorang pendidik meningkatkan kualitasnya sehingga dapat menjajarkan pengetahuan dengan tuntutan zaman sekarang ini. Setiap pendidik professional diharapkan harus mempunyai kompetensi dan penguasaan yang mendalam dalam bidangnya. Penguasaan pengetahuan inilah yang menjadi syarat penting di samping keterampilan keterampilan lainnya (Sum \& Taran, 2020).

Peran Pendidik PAUD dalam melaksanakan pembelajaran pada Kelompok Bermain, Pos PAUD maupun bentuk pendidikan anak Usia Dini lainnya memang dituntut bertindak 
profesional, dalam artian bahwa peran pendidik PAUD sebagai pelaksana teknis fungsional dalam kegiatan pembelajaran mempunyai tugas untuk melaksanakan kegiatan pembelajaran pada pendidikan anak usia dini secara profesional sesuai dengan norma seorang pendidik (Zubaidi, 2020).

Guru harus mampu mengantarkan peserta didik sesuai tujuan pendidikan nasional dan bersaing dengan kemajuan zaman tersebut. Walaupun guru dan pengajar bukan satu-satunya faktor penentu keberhasilan pendidikan tetapi pengajaran merupakan tiitk sentral pendidikan dan kualifikasi sebagai cermin kualitas tenaga pengajar yang memberikan andil sangat besar bagi kualitas pendidikan yang menjadi tanggung jawabnya (Yuliariatiningsih \& Setiaty, 2018). Dasar dari proses sebuah pendidikan adalah pembelajaran. Dalam pembelajaran terdapat proses hubungan antara sumber belajar, pendidik, dan peserta didik. Proses hubungan tersebut dilakukan baik secara tersirat ataupun tersurat.

Selain itu, di dalam pembelajaran juga terdapat beberapa hubungan yang saling terkait antara satu sama lain yaitu input, proses, dan output. Yang dimaksud dengan input adalah materi pembelajaran, proses yaitu kegiatan dalam pembelajaran, dan output adalah hasil dari materi kegiatan pembelajaran. Dalam mengetahui keberhasilan pembelajaran perlu diadakannya evaluasi. Evaluasi itu sendiri berasal dari kata evaluation, al-taqdir, dan penilaian. Secara istilah, evaluasi merupakan suatu aktivitas, cara, atau metode dalam menentukan nilai dari sesuatu (Sudjono, 2015). Menurut Suryosubroto, proses belajar mengajar meliputi kegiatan yang dilakukan guru mulai dari perencanaan, pelaksanaan kegiatan sampai evaluasi dan program tindak lanjut yang berlangsung dalam situasi edukatif untuk mencapai tujuan tertentu yaitu pengajaran (Werdayanti, 2008).

Di Indonesia, secara umum evaluasi pendidikan dilakukan melalui berbagai pendekatan seperti kegiatan Monitoring and Evaluation (Monev) atau supervisi yang dilakukan oleh pengawas pendidikan dan evaluasi pendidikan oleh Badan Akreditasi Nasional (BAN) melalui akreditasi. Namun demikian, evaluasi pendidikan tersebut masih belum efektif dalam memberikan umpan balik (feedback) bagi lembaga pendidikan untuk memahami apa saja yang menjadi area yang sudah baik dan area yang perlu ditingkatkan (Utami et al., 2020).

Menurut Suchman, evaluasi adalah sebuah cara untuk menentukan hasil yang telah dicapai dari beberapa kegiatan yang direncanakan untuk mendukung tercapainya suatu tujuan 
dalam pembelajaran. Sedangkan pengertian evaluasi menurut Worthen dan Sanders adalah tindakan dalam mencari sesuatu yang berharga tentang sesuatu; dalam pencarian tersebut termasuk mencari informasi yang bermanfaat dalam menilai eksistensi suatu program, penerapan, proses, serta pilihan rencana yang diajukan untuk mencapai tujuan yang telah ditentukan sebelumnya (Rukajat, 2018).

Evaluasi dilakukan untuk mengoptimalkan seluruh bagian kelanjutan pada anak seperti perubahan kognitif, perubahan motorik, perubahan sosial emosional, perubahan bahasa, perubahan seni, dan perubahan moral agama. Tindakan penilaian diolaksanakan secara komprehensif yang sesuai dengan prinsip-prinsip penilaian pada pendidikan anak usia dini antara lain yaitu mendidik, berkesinambungan, objektif, akuntabel, transparan, sistematis, menyeluruh, dan bermakna (Kebudayaan, 2015).

Seseorang yang memiliki kompetensi yang baik akan terus menerus melakukan kegiatan yang mencerminkan pengetahuan, keterampilan dan nilai dasar yang harus dimiliki oleh guru. Hal ini diperkuat oleh pernyataan Pusat kurikulum Depdiknas, yang menyatakan kompetensi merupakan pengetahuan, keterampilan, dan nilai dasar yang direfleksikan dalam kebiasaan berfikir dan bertindak secara konsisten dan terus menerus (Meutia \& Mursita, 2018).

Seorang guru harus memiliki kompetensi pedagogik, dimana seorang guru memiliki kemampuan dalam melaksanakan pembelajaran, baik dalam mengelola, melaksanakan pembelajaran dan melakukan evaluasi pembelajaran (Meutia \& Mursita, 2018). Kompetensi pedagogik merupakan kemampuan guru dalam mengelola pembelajaran. kompetensi ini meliputi pemahaman tentang wawasan atau landasan kependidikan, pemahaman terhadap peserta didik, pengembangan kurikulum atau silabus, perancangan pembelajaran, pelaksanaan pembelajaran yang mendidik dan dialogis, pemanfaatan teknologi pembelajaran, evaluasi proses dan hasil belajar, serta pengembangan peserta didik untuk mengaktualisasikan berbagai potensi yang dimilikinya (Lina et al., 2019). Seorang guru yang memiliki kompetensi kepribadian yang baik maka guru tersebut akan memberikan teladan yang baik bagi para peserta didiknya, guru akan bersikap dewasa, berwibawa dan bersikap manusiawi (Meutia \& Mursita, 2018).

Tanpa disadari seringkali guru setelah selesai mengajar menganggap bahwa pembelajaran sudah terlaksana. Sebenarnya jika kita tidak memiliki sesuatu bukti tingkah 
laku dari hasil pembelajaran tersebut, sebetulnya pembelajaran belum terlaksana. Asumsi yang menganggap bahwa pembelajaran sudah terlaksana sebelum memiliki sesuatu bukti tingkah laku dari hasil pembelajaran merupakan alasan yang tidak mendasar, dan kita jangan puas dengan itu. Dengan kata lain konsekwensi-konsekwensi yang mendatangkan malapetaka dari kebiasaan menerima dan yakin bahwa pembelajaran sudah terlaksana setelah selesai guru mengajar saja atau hanya disebabkan oleh materi pelajaran yang telah disampaikan. Atau bisa dikatakan merupakan malapetaka dalam pendidikan bila seorang guru menganggap bahwa pembelajaran telah terlaksana hanya setelah mengajar saja atau setelah menyampaikan materi pelajaran. Jika hanya begitu saja maka ini merupakan malapetaka (Lase, 2015).

Kedudukan guru dalam Undang-undang Nomor 15 Tahun 2005 pada Bab II Pasal 2 adalah sebagai tenaga profesional khususnya pada jalur formal untuk jenjang pendidikan anak usia dini. Bahkan dinyatakan bahwa pengakuan kedudukan guru sebagai tenaga profesional dibuktikan dengan sertifikat pendidik. Kedudukan guru sebagai tenaga profesional berfungsi untuk meningkatkan martabat dan peran guru sebagai agen pembelajaran yang berfungsi untuk meningkatkan mutu pendidikan nasional (Yuslam et al., 2017).

Peran guru dalam proses belajar mengajar salah satunya adalah sebagai evaluator. Ketika dalam proses pembelajaran hendaknya pendidik menjadi evaluator yang produktif. Hal ini dimaksudkan untuk memahami apakah tujuan evaluasi yang telah dirumukan itu sudah tercapai atau belum, apakah materi yang diberikan kepada peserta didik sudah sahih. Hal ini akan terjawab melalui kegiatan evaluasi oleh pendidik (Nuriyah, 2014).

Ketika pendidik telah memahami dan melaksanakan tugasnya dengan efektif maka kinerjanya sudah baik. Tugas pokok pendidik dalam pembelajaran yaitu merumuskan kegiatan atau program dalam pembelajaran, melaksanakan program pembelajaran, melakukan evaluasi, menganalisis hasil pembelajaran, serta adanya tindak lanjut dari hasil pembelajaran yang telah dilaksanakan itu (Hosnan, 2014). Hasil pembelajaran yang berkualitas akan berpengaruh pada prestasi belajar yang diperoleh siswa. Dalam mendorong semangat belajar siswa untuk meningkatkan prestasi belajar dan memahami economic literacy, guru harus bisa memahami karakter siswa, melakukan perancangan pembelajaran, melakukanevaluasi pembelajaran dan bahkan dituntut untuk bisa mengaktualisasikan berbagai potensi yang dimiliki siswa (Sum \& Taran, 2020). Dalam evaluasi pembelajaran terdapat prosedur yang 
harus dilakukan oleh pendidik. Menurut E. Mulyasa, prosedur evaluasi pembelajaran pada anak usia dini adalah sebagai berikut: (Mulyasa, 2015)

1. Merumuskan/menetapkan kegiatan

2. Menyiapkan alat penilaian

3. Menetapkan kriteria penilaian

4. Mengumpulkan data

5. Menentukan nilai

Sebagaimana menurut Eka Damayanti,dkk., Fakultas Tarbiyah dan Keguruan, Prodi Pendidikan Islam Anak Usia Dini tahun 2018 yang meneliti mengenai Manajemen Penilaian PAUD di TK Citra Semata kabupaten Gowa. Dengan hasil bahwa proses penilaian dilakukan melalui lima tahap, yakni tahap perencanaan, tahap pelaksanaan atau pencatatan, pengolahan hasil belajar, pengarsipan, dan pelaporan (Damayanti et al., 2018). Hal serupa juga di lakukan Hani terkait evaluasi pembelajaran PAUD, hasil penelitian menemukan bahwa pada penilaian observasi di PAUD memiliki beberapa cara observasi yang kelebihan dan kekurangan masing-masing. Kelebihan dan kekurangan ini dapat digunakan oleh guru untuk menentukan cara evaluasi yang tepat sesuai dengan perencanaan pembelajaran (Hani, 2019).

Keadaan lapangan di Taman Kanak-kanak Dharma Wanita Persatuan belum mampu mengimplementasikan evaluasi pembelajaran yang seharusnya. Berdasarkan data yang diperoleh bahwasannya dalam pelaksanaan evaluasi pembelajaran anak usia dini, pendidik tidak melaksanakan sesuai dengan prosedur evaluasi yang ada. Pendidik hanya melaksanakan empat dari lima indiktor yang ada, antara lain merumuskan atau menetapkan kegiatan, menyiapkan alat penilaian, menetapkan kriteria penilaian, dan menentukan nilai. Teknik penilaian yang dilakukan oleh pendidik adalah melalui metode non tes. Metode non tes yang digunakan di lembaga pendidikan itu meliputi pengamatan, tanya jawab, hasil karya, unjuk kerja, dan rating scale. Dalam evaluasi pembelajaran berbentuk rating scale dilakukan secara keseluruhan dalam artian terkadang guru menilai dengan mensamaratakan perkembangan antara peserta didik satu dengan yang lainnya.

Dalam kondisi sebagaimana diuraikan, dibutuhkan penelitian lebih lanjut mengenai Implementasi Evaluasi Pembelajaran Anak Usia Dini di Taman Kanak-kanak Dharma Wanita Persatuan Bandar Lampung. 


\section{METODE PENELITIAN}

Metode penelitian adalah suatu cara kerja agar dapat mengumpulkan data dan data tersebut diolah untuk menghasilkan data yang dapat memecahkan permasalahan penelitian. Metode Penelitian ini menggunakan metode penelitian deskriptif. Penelitian Deskriptif adalah penelitian yang berusaha mendeskripsikan suatu gejala, peristiwa, kejadian yang terjadi saat sekarang.(Apriyanti, 2017).

Subjek dalam penelitian ini ialah semua yang terlibat dalam pelaksanaan evaluasi pembelajaran anak usia dini di taman kanak-kanak dharma wanita persatuan bandar lampung, baik peserta didik, tenaga kependidikan juga yang lainya, yang penulis anggap mampu untuk dijadikan sebagai informan untuk memperoleh data yang penulis harapkan. Sedangkan obyek penelitian ini yaitu tentang bagaimana implementasi evaluasi pembelajaran anak usia dini di taman kanak-kanak dharma wanita persatuan bandar lampung.

Dalam prosedur pengumpulan data dalam penelitian ini, peneliti melaksanakan pengumpulan data dengan menggunakan observasi, wawancara, dan dokumentasi. Observasi diartikan sebagai pengamatan dan pencatatan secara sistematik terhadap gejala yang tampak pada objek penelitian. Adapun yang akan di observasi adalah mengenai bagaimanakah implementasi evaluasi pembelajaran anak usia dini yang dilaksanakan oleh pendidik. Peneliti mencatat semua hal-hal yang diperlukan dan terjadi selama pelaksanaan tindakan berlangsung. Lembar observasi dijadikan pedoman oleh peneliti agar ketika melakukan observasi akan lebih terarah dan terukur sehingga hasil data yang telah didapatkan sebelumnya mudah untuk diolah. Wawancara merupakan pertemuan dua orang untuk bertukar informasi dan idea melalui tanya jawab, sehingga didapatkan makna dalam suatu topik tertentu. Untuk wawancara, peneliti akan melaksanakan wawancara kepada pendidik yang ada di lembaga tersebut yaitu kepala sekolah dan pendidik. Dengan menggunakan instrumen wawancara yang telah dipersiapkan oleh penulis. Dokumentasi adalah pencarian data mengenai variable berupa catatan-catatan yang diperlukan oleh peneliti. Dokumentasi digunakan dalam penelitian ini berupa foto kegiatan yang sedang berlangsung dengan mengumpulkan Rencana Pelaksanaan Pembelajaran Harian (RPPH), visi dan misi sekolah, proses pembelajaran yang dilakukan oleh pendidik terhadap peserta didiknya, serta sara prasarana di Taman Kanak-kanak Dharma Wanita Persatuan Bandar Lampung. 
Prosedur analisis data yang digunakan oleh peneliti yaitu reduksi data, display data, dan verifikasi. Adapun reduksi data menggunakan hasil observasi dan wawancara dan dirangkum satu persatu agar memudahkan peneliti dalam memfokuskan data. Data yang tidak terkait dengan permasalahan tidak disajikan dalam bentuk laporan. Kemudian display data menggunakan cara menyajikan inti pokok data yang mencakup hasil keseluruhan penelitian yang telah dilakukan penulis tentang implementasi evaluasi pembelajaran anak usia dini di taman kanak-kanak dharma wanita persatuan bandar lampung. Sedangkan verifikasi didapatkan dari temuan mengenai implementasi evaluasi pembelajaran anak usia dini di taman kanak-kanak dharma wanita persatuan bandar lampung yang diperoleh dari data penelitian yang dilakukan oleh peneliti.

\section{HASIL PENELITIAN DAN PEMBAHASAN}

\section{A. Hasil Penelitian}

Dalam bab ini penulis ingin membahas mengenai pengolahan data dan analisis data. Adapun data yang diolah dan dianalisis data dalam bab ini yaitu data kualitatif dengan alat pengambilan datanya melalui observasi, wawancara, dan dokumentasi pada guru dan anak mengenai implementasi evaluasi pembelajaran anak usia dini di Taman Kanakkanak Dharma Wanita Persatuan Bandar Lampung.

Penelitian ini dilakukan di Taman Kanak-kanak Dharma Wanita Persatuan Bandar Lampung mulai tanggal 26 Februari 2020 sampai dengan 26 April 2020.

Penelitian diawali dengan observasi yang dilakukan penulis di Taman Kanak-kanak Dharma Wanita Persatuan Bandar Lampung untuk mengamati implementasi evaluasi pembelajaran anak usia dini. Sehingga untuk menganalis datanya penulis menggunakan metode deskriptif.

\section{B. PEMBAHASAN}

Berdasarkan hasil observasi dan wawancara yang dilakukan oleh peneliti di Taman Kanak-kanak Dharma Wanita Persatuan Bandar Lampung dapat diuraikan bahwa Implementasi Evaluasi Pembelajaran Anak Usia Dini adalah sebagai berikut:

\section{Merumuskan dan menetapkan kegiatan}

Dalam menentukan kegiatan, pendidik melakukan perumusan program semester (PROSEM) hingga sampai rencana pelaksanaan pembelajaran harian (RPPH) di taman kanak-kanak dharma wanita bandar lampung sehingga kegiatan 
ataupun evaluasi untuk proses pembelajaran akan terorganisir dengan baik sesuai dengan tema dan sub tema yang ada pada kurikulum. Setelah adanya penentuan kegiatan maka adanya penentuan aspek-aspek yang akan dievaluasi. Karena ini adalah bentuk evaluasi pada anak usia dini maka melibatkan seluruh enam aspek perkembangan pada anak usia dini yaitu perkembangan moral agama, perkembangan kognitif, perkembangan motorik, perkembangan sosial emosional, perkembangan bahasa, dan perkembangan seni.

\section{Menyiapkan alat atau teknik penilaian}

Setelah adanya penentuan aspek-aspek perkembangan yang akan dievaluasi, langkah yang selanjutnya adalah menentukan teknik-teknik yang akan digunakan. Adapun teknik evalalusi pembelajaran yang digunakan disini adalah berupa pengamatan, tanya jawab, hasil karya, unjuk kerja, dan rating scale.

\section{Menetapkan kriteria penilaian}

Setelah menentukan alat atau teknik-teknik yang akan digunakan, langkah selanjutnya adalah menetukan tolak ukur atau kriteria dalam penilaian. Berikut adalah penggunaan alat atau teknik penilaian yang penulis dapatkan ketika penelitian di taman kanak-kanak dharma wanita persatuan bandar lampung.

a. Pengamatan atau observasi

Pengamatan ini dilaksanakan dengan cara pendidik mengamati segala perubahan atau perilaku peserta didiknya dalam periode waktu tertentu.

b. Tanya jawab atau wawancara

Tanya jawab atau wawancara ini dilakukan oleh pendidik secara pretest dan postest. Pretes dilakukan ketika sebelum proses pembelajaran di mulai. Pendidik bertanya kepada peserta didik mengenai tema atau subtema yang akan dipelajari pada saat itu. Sedangkan postest dilakukan ketika sesudah proses pembelajaran telah selesai. Biasanya pendidik mengadakan postest ini sebelum waktu pulang tiba. Jadi, pendidik dapat mengetahui bagaimana perkembangan peserta didiknya sebelum dan sesudah tema atau subtema itu dilakukan. Terdapat perubahan atau tidak pada peserta didiknya.

c. Hasil karya

Hasil karya merupakan pekerjaan tangan peserta didik setelah terlaksanakanya suatu kegiatan seperti keterampilan tangan, karya seni. Bentuk dari hasil karya 
ini seperti mewarnai, melipat, mengkolase, menempel, dan lain-lain. Adapun format penilaian hasil karya peserta didik di lembaga pendidikan ini adalah

$\mathrm{O} \quad$ : baik tetapi perlu adanya bimbingan dari pendidik

$\checkmark \quad$ :sangat baik, harus ditingkatkan

d. Unjuk kerja

Unjuk kerja adalah penampilan. Penerapan metode penilaian unjuk kerja ini seperti berjalan diatas papan, berwudhu, dan lain sebagainya.

e. Rating scale atau checklist

Rating scale adalah salah satu teknik evaluasi yang dilakukan dengan cara menceklis butir-butir atau item dalam skala capaian perkembangan anak.

\section{Mengumpulkan data}

Mengumpulkan data belum dilakukan di Taman Kanak-kanak Dharma Waita Persatuan Bandar Lampung. Pendidik tidak mengumpulkan semua hasil karya peserta didik dalam map yang telah disediakan. Ketika sudah diberi tanda $\mathrm{O}$ dan pada hasil karya peserta didik, guru mengembalikannya untuk dibawa pulang oleh peserta didik. Sedangkan melalui kumpulan hasil karya peserta didik yang terdapat di dalam map, pendidik dapat mengetahui perkembangan peserta didiknya dari pencapaian hasil karya sebagai bukti dari hasil kegiatan pembelajaran yang telah dilakukan sebelumya.

\section{Menentukan nilai}

Berdasarkan dari data yang telah diperoleh, maka pendidik akan mengolahnya serta mendeskripsikan atau memberikan kesimpulan dari hasil pelaksanaan evaluasi sehingga akhirnya akan memperoleh gambaran tentang perkembangan anak atau hal lainnya yang berkaitan dengan pembelajaran di pendidikan anak usia dini.

Sesudah adanya pengolahan dan pendeskripsian, pendidik mencatatnya dalam laporan pendidikan anak. Pelaporan adalah suatu aktivitas guna menjelaskan hasil penilaian guru mengenai pertumbuhan dan perkembangan anak. Tujuan pemberian penjelasan ini antara lain agar para orang tua atau wali murid mengetahui tentang perkembangan anaknya selama berada di lembaga pendidikan anak usia dini.

Bentuk pelaporan di taman kanak-kanak dharma wanita persatuan bandar lampung berupa penilaian ceklis dan deskripsi. Selanjutnya pendidik dapat mengambil 
keputusan atau merumuskan kebijakan-kebijakan yang dipandang perlu sebagai tindak lanjut dari kegiatan evaluasi.

Adapun hal yang sudah dilaksanakan oleh guru namun dalam pelaksanaannya belum berkembang secara maksimal yaitu pada saat mengumpulkan data. Pendidik kurang untuk mengumpulkan data hasil kegiatan pembelajaran. Seharusnya pendidik secara rutin mengumpulkan data hasil kegiatan pembelajaran pada peserta didik yang telah dilakukan tersebut supaya dalam pelaksanaan rekapitulasi penilaian nantinya pendidik tidak kesulitan dalam mendeskripsikan hasil pembelajaran pada peserta didik.

\section{SIMPULAN DAN SARAN}

\section{A. Kesimpulan}

Berdasarkan hasil analisis dan pembahasan sebelumnya, maka yang peneliti dapat simpulkan mengenai Implementasi Evaluasi Pembelajaran Anak Usia Dini di Taman Kanak-kanak Dharma Wanita Persatuan Bandar Lampung. Adapun hasil penelitian yang dilakukan pendidik dalam evaluasi pembelajaran anak usia dini adalah sebagai berikut (1) Merumuskan atau menetapkan kegiatan (2) Menyiapkan alat atau teknik penilaian (3) Menetapkan kriteria penilaian (4) Mengumpulkan data (5) Menentukan nilai.

Berdasarkan penelitian yang peneliti lakukan bahwa pendidik belum sepenuhnya menerapkan prosedur dalam evaluasi pembelajaran anak usia dini. Dalam prosedur evaluasi pembelajaran anak usia dini, pada tahap mengumpulkan data tidak dilakukan oleh guru. Sehingga dari kelima prosedur evaluasi tersebut ada satu yang kurang maksimal dalam penerapannya yaitu dalam mengumpulkan data kegiatan pembelajaran. Pendidik kurang untuk mengumpulkan data hasil kegiatan pembelajaran. Seharusnya pendidik secara rutin mengumpulkan data hasil kegiatan pembelajaran pada peserta didik yang telah dilakukan tersebut supaya dalam pelaksanaan rekapitulasi penilaian nantinya pendidik tidak kesulitan dalam mendeskripsikan hasil pembelajaran pada peserta didik.

\section{B. Saran}

Berdasarkan kesimpulan dari hasil penelitian dan pembahasan, maka penulis dapat mengemukakan saran berikut: 1) Sebaiknya pendidik melakukan tahapan evaluasi dengan baik sehingga dalam pengisian nilai raport tidak kesulitan dalam menganalisis evaluasi hariannya. 2) Jika pendidik merasa kesulitan karena banyaknya peserta didik yang harus dinilai, pendidik bisa memfokuskan beberapa peserta didik di setiap harinya dan itu dilaksanakan secara bergantian, sehingga dalam subtema itu semua peserta didik 
bisa teramati dan tercatat perkembangannya. 3) Kepala sekolah diharapkan dapat berbagi pengalamannya bersama pendidik guna menambah pengetahuan dan wawasan mengenai evaluasi pembelajaran anak di lembaga pendidikan anak usia dini.

\section{DAFTAR PUSTAKA}

Anggraini, W., \& Kuswanto, C. W. (2019). Teknik Ceklist Sebagai Asesmen Perkembangan Sosial Emosional di RA. Al-Athfaal: Jurnal Ilmiah Pendidikan Anak Usia Dini, 2(2), 61-70. https://doi.org/10.24042/ajipaud.v2i2.5248

Apriyanti, H. (2017). Pemahaman Guru Pendidikan Anak Usia Dini Terhadap Perencanaan Pembelajaran Tematik. Jurnal Obsesi : Jurnal Pendidikan Anak Usia Dini, 1(2), 111. https://doi.org/10.31004/obsesi.v1i2.22

Damayanti, E., Hartika, A. S., \& Herawati. (2018). Manajemen Penilaian PAUD di TK Citra Semata. NANAEKE Indonesian Journal of Early Childhood Education, 1.

Dewi, I., \& Suryana, D. (2020). Analisis Evaluasi Kinerja Pendidik di PAUD Al-Azhar Bukittinggi. Obsesi, 4(2). https://doi.org/10.31004/obsesi.v4i2.465

Dewi, K. (2017). Pentingnya Media Pembelajaran untuk Anak Usia Dini. Raudhatul Athfal, 1. https://doi.org/https://doi.org/10.19109/ra.v1i1.1489

Hani, A. A. (2019). Evaluasi Pembelajaran Pada PAUD. Care, 7(1), 52-56.

Hosnan, M. (2014). Pendekatan Saintifik dan Kontekstual Dalam Pembelajaran Abad 21. PT. Thalia Indonesia.

Kebudayaan, K. P. dan. (2015). Penilaian Pembelajaran PAUD.

Lase, F. (2015). Dasar Pengembangan Kurikulum Menjadi Pengalaman Belajar. Obsesi, 1. https://doi.org/https://doi.org/10.31004/obsesi.v1i2.68

Lina, L., Suryana, D., \& Nurhafizah, N. (2019). Penerapan Model Evaluasi CIPP dalam Mengevaluasi Program Layanan PAUD Holistik Integratif. Obsesi, 3(2). https://doi.org/10.31004/obsesi.v3i2.200 
Meutia, V., \& Mursita, R. A. (2018). Kompetensi Pedadogik Guru Kelas dalam Pembelajaran Peserta Didik Tunarungu. Cakrawala, 9. https://doi.org/https://doi.org/10.17509/cd.v9i1.11345

Mulyasa, E. (2015). Manajemen PAUD. PT. Remaja Rosdakarya.

Munawaroh, H. (2017). Pengembangan Model Pembelajaran dengan Permainan Tradisional Engklek Sebagai Sarana Stimulasi Perkembangan Anak Usia Dini. Obsesi, 1(2), 86-96. https://doi.org/10.31004/obsesi.v1i2.19

Nuriyah, N. (2014). Evaluasi Pembelajaran: Sebuah Kajian Teori. Edueksos: Jurnal Pendidikan Sosial Dan Ekonomi, 3(1), 73-86.

Roza, D., Nurhafizah, \& Yaswinda. (2020). Urgensi Profesionalisme Guru Pendidikan Anak Usia Dini dalam Penyelenggaraan Perlindungan Anak. Obsesi, 4(1). https://doi.org/10.31004/obsesi.v4i1.325

Rukajat, A. (2018). Teknik Evaluasi Pembelajaran. Deepublish.

Sari, K. M., \& Setiawan, H. (2020). Kompetensi Pedadogik Guru Dalam Melaksanakan Penilaian Pembelajaran Anak Usia Dini. Obsesi, 4(2). https://doi.org/10.31004/obsesi.v4i2.278

Sudjono, A. (2015). Pengantar Evaluasi Pendidikan. Rajawali Pers.

Sum, T. A., \& Taran, E. G. M. (2020). Kompetensi Pedadogik Guru PAUD dalam Perencanaan dan Pelaksanaan Pembelajaran. Obsesi, 4(2). https://doi.org/10.31004/obsesi.v4i2.287

Uce, L. (2015). The Golden Age. Bunayya: Jurnal Pendidikan Anak, 1(2), 77-92.

Utami, W. Y. D., Jamaris, M., \& Meilanie, S. M. (2020). Evaluasi Program Pengelolaan Lembaga PAUD di Kabupaten Serang. Obsesi, 4(1). https://doi.org/10.31004/obsesi.v4i1.259

Werdayanti, A. (2008). Pengaruh Kompetensi Guru dalam Proses Belajar Mengajar di Kelas dan Fasilitas Guru terhadap Motivasi Belajar Siswa. Pendidikan Ekonomi, 3. https://doi.org/https://doi.org/10.15294/dp.v3i1.434 
Wiyani, N. A. (2015). Manajemen PAUD Bermutu. Gava Media.

Yuliariatiningsih, M. S., \& Setiaty, T. (2018). KOMPETENSI PEDAGOGIK GURU PAUD DALAM MENGEMBANGKAN PEMBELAJARAN UNTUK ANAK USIA DINI. Cakrawala Dini: Jurnal Pendidikan Anak Usia Dini, 3(1). https://doi.org/10.17509/cd.v3i1.10325

Yuslam, Setiani, R. E., \& Sari, A. K. (2017). Studi Tentang Kompetensi Guru PAUD Berkualifikasi Akademik Sarjana PG-PAUD dan NonPG-PAUD di PAUD Istiqomah Sambas Purbalingga. Al-Athfal, 3. https://doi.org/https://doi.org/10.14421/alathfal.2017.32-04

Zubaidi, M. (2020). Profesionalisme Guru dan Efektifitas Pembelajaran pada Pendidikan Anak Usia Dini. Obsesi, 4(2). https://doi.org/10.31004/obsesi.v4i2.505 